\begin{tabular}{llll}
\hline DE & DE GRUYTER & $\begin{array}{c}\text { HUNGARIAN JOURNAL OF } \\
\text { OPEN }\end{array}$ & $\begin{array}{c}\text { INDUSTRY AND CHEMISTRY } \\
\text { Vol. 44(1) pp. 33-38 (2016) } \\
\text { hjic.mk.uni-pannon.hu } \\
\text { DOl: 10.1515/hic-2016-0004 }\end{array}$
\end{tabular}

\title{
VAPOUR PRESSURE OF ETHANOL AND 1-PROPANOL BINARY MIXTURES
}

\author{
MISIRKHAN TALIBOV ${ }^{1}$ AND JAVID SAFAROV $V^{1,2}$ \\ ${ }^{1}$ Department of Heat and Refrigeration Techniques, Azerbaijan Technical University, H. Javid Ave. \\ 25, AZ1073 Baku, AZERBAIJAN \\ ${ }^{2}$ Institute of Technical Thermodynamics, University of Rostock, Albert-Einstein Str. 2, D-18059 \\ Rostock, GERMANY
}

\begin{abstract}
The vapour pressure of binary mixtures containing ethanol and 1-propanol were investigated at temperatures ranging from 274.15 to $443.15 \mathrm{~K}$ using two different setups with static methods. The measured values were fitted to a Clausius-Clapeyron type relationship. The heat of evaporation of mixtures was determined from the vapour-liquid equilibria data.
\end{abstract}

Keywords: vapour pressure, ethanol, 1-propanol, static method, pressure transmitters, ClausiusClapeyron equation

\section{Introduction}

Investigation of thermodynamic properties of pure liquids and their mixtures is important in various fields of science, chemical engineering, economy and industry. Aliphatic alcohols are commonly applied in chemical, biological, and medical uses as solvents for fats, oils, resins, paints, and nitrocellulose with regard to the manufacture of goods from perfumes to brake fluids [1]. In addition, the studied solutions of ethanol $\left(\mathrm{C}_{2} \mathrm{H}_{5} \mathrm{OH}\right)$ and 1-propanol $\left(\mathrm{C}_{3} \mathrm{H}_{7} \mathrm{OH}\right)$ are also used as heat transfer fluids in heat reservoirs, solar heating systems, oxygenates in fuels, and cryogenic power generation systems [2]. For the design and modelling of such applications, the determination of flow in pipes, heat transfer, and mass transfer operations requires the knowledge of thermophysical properties. Density, vapour pressure, speed of sound, viscosity, and heat capacity often need to be defined for these purposes.

This work is a continuation of our previous publications in the field of thermophysical properties of alcohol and their solutions [3-6]. Hereby, the vapour pressure of binary solutions of $(1-x) \quad \mathrm{C}_{2} \mathrm{H}_{5} \mathrm{OH}+x$ $\mathrm{C}_{3} \mathrm{H}_{7} \mathrm{OH}$ were investigated. The vapour pressure data of binary solutions of ethanol and 1-propanol at different temperatures and concentrations were determined. After the analysis of the literature using "ThermoLit" from NIST, we concluded that only a few vapour pressure values for these systems have been reported to date [7-11].

*Correspondence: javid.safarov@uni-rostock.de
Early studies by Parks and Schwenk [7] reported the vapour pressure of a $(1-x) \mathrm{C}_{2} \mathrm{H}_{5} \mathrm{OH}+x \mathrm{C}_{3} \mathrm{H}_{7} \mathrm{OH}$ mixture at $298.15 \mathrm{~K}$ using glass apparatus and the differential method. A good commercial grade ethanol $(w=99.9 \%)$ and "refined" commercial 1-propanol $(w=$ $99.34 \%$ ) were used during the preparation of solutions. Later, Udovenko and Frid [8] investigated the vapour pressure of the same mixture, but within a higher temperature range (323.15 to $353.15 \mathrm{~K})$ using the dynamic method. The vapour liquid equilibria (VLE) of these systems were analysed using a refractometer. The activity coefficients $\gamma$ of both pure components were calculated.

A series of studies in the early 90 s included the work of Zielkiewicz [9], who studied the vapour pressure at $313.15 \mathrm{~K}$ using the static method. Dried ethanol and 1-propanol were used during the preparation of solutions. The temperature and pressure were controlled within $\pm 0.001 \mathrm{~K}$ and $\pm 0.004 \mathrm{kPa}$, respectively. Binary samples were prepared by weighing within an uncertainty of \pm 0.0005 mole fractions. Solution preparations were carried out using the dry nitrogen process. Furthermore, Pradhan et al. [10] investigated the vapour pressures of ethanol and 1propanol solutions at $303.15 \mathrm{~K}$ using the static method. For the fitting of obtained values a modified NRTL equation was used.

Quite recently, Cristino et al. [11] carried out high temperature VLE measurements for the system of ethanol and 1-propanol solutions within a temperature range of 403.2 to $423.2 \mathrm{~K}$ using a flow apparatus. Alcohols used during the preparation of solutions had a confirmed purity greater than 99.9 weight percent. The pressure was controlled using two pressure transducers within ranges of $0-0.4$ (uncertainty of $\pm 0.0002 \mathrm{MPa}$ ) and $0-1.7 \mathrm{MPa}$ (uncertainty of $\pm 0.0009 \mathrm{MPa}$ ). The 
Table 1. Summary of the vapour pressure $P$ literature investigations of a (1-x) $\mathrm{C}_{2} \mathrm{H}_{5} \mathrm{OH}+x \mathrm{C}_{3} \mathrm{H}_{7} \mathrm{OH}$ mixture.

\begin{tabular}{|c|c|c|c|c|c|c|c|c|}
\hline Reference & Method & Properties & $\begin{array}{l}\text { Temperature } \\
(T \text { in } K)\end{array}$ & $\begin{array}{c}\text { Concentration } \\
(x \text { mole fraction }) \\
\end{array}$ & $\begin{array}{c}\text { Uncertainty } \\
\Delta P \\
\end{array}$ & $\begin{array}{c}\text { Fitted density } \\
\text { equation }\end{array}$ & Purity & Source \\
\hline Parks [7] & GA & $P, T, \Delta H$ & 298.15 & 0.0000 to 1.0000 & & & $99.9 \%(\mathrm{Et})$ & $\mathrm{CS}$ \\
\hline 1924 & & & & & & & $99.34 \%(\mathrm{Pr})$ & \\
\hline $\begin{array}{l}\text { Udovenko [8] } \\
1948\end{array}$ & DM & $P, T, \gamma$ & $323.15-353.15$ & 0.0000 to 1.0000 & & $\mathrm{CC}$ & $\begin{array}{l}\text { ARG (Et) } \\
\text { ARG (Pr) }\end{array}$ & $\mathrm{R}$ \\
\hline $\begin{array}{l}\text { Zielkiewicz [9] } \\
1993\end{array}$ & SM & $P, T$ & 313.15 & 0.0436 to 0.9291 & $\pm 0.004 \mathrm{kPa}$ & & & $\mathrm{POCh}$ \\
\hline $\begin{array}{l}\text { Pradhan [10] } \\
1993\end{array}$ & SM & $P, T$ & 303.15 & 0.0306 to 0.9700 & $\pm 0.001 \mathrm{kPa}$ & & $\begin{array}{l}99.9 \%(\mathrm{Et}) \\
99.6 \%(\mathrm{Pr})\end{array}$ & $\mathrm{AC}$ \\
\hline $\begin{array}{l}\text { Cristino [11] } \\
2015\end{array}$ & FA & $P, T, \mathrm{VLE}$ & $403.20-423.20$ & 0.0017 to 0.9993 & $\begin{array}{l} \pm 0.0002- \\
\pm 0.0009 \mathrm{MPa}\end{array}$ & SAFT-VR & $\begin{array}{l}99.9 \%(\mathrm{Et}) \\
99.9 \%(\mathrm{Pr})\end{array}$ & $\begin{array}{l}\mathrm{P}(\mathrm{Et}) \\
\text { FS (Pr) }\end{array}$ \\
\hline
\end{tabular}

temperature was measured using a platinum resistance thermometer with an uncertainty of $\pm 0.1 \mathrm{~K}$. The statistical associating fluid theory for potentials of variable range (SAFT-VR) was used to model the systems and found to accurately reproduce the experimental data. Using this analytical method the uncertainty of solution preparation was \pm 0.0001 mole fractions.

The outcome of a literature survey summarised in Table 1 is that only small temperature, pressure, and concentration intervals were investigated to date in addition to older literature examples decades ago that may have used out-dated measurement techniques.

In this work, the vapour pressures of binary (1-x) $\mathrm{C}_{2} \mathrm{H}_{5} \mathrm{OH}+x \mathrm{C}_{3} \mathrm{H}_{7} \mathrm{OH}$ solutions were investigated using two highly accurate, fully automatic static experimental setups and ultrapure Merck quality chemicals.

\section{Experimental}

\subsection{Samples and Measurements}

Ultra-pure ethanol EMPLURA ${ }^{\circledR}(w=99.995 \%$, CAS No. 71-36-3, Art. Nr. 8.22262.2500) and 1-propanol Analyse EMSURE® ACS, Reag. Ph Eur $(w=99.995 \%$, CAS No. 71-23-8, Art. Nr. 1009971000) were purchased from Merck Schuchardt OHG, Germany. The samples were used without further purification. They were carefully degassed in glass flasks with special vacuum leak-proof valves before measurements were taken. The water content is determined by Karl Fischer titration and was determined to be less than a mass fraction of $20 \mathrm{ppm}$.

\subsection{Experimental Procedure}

The vapour pressure measurements of binary solutions of $(1-x) \mathrm{C}_{2} \mathrm{H}_{5} \mathrm{OH}+x \mathrm{C}_{3} \mathrm{H}_{7} \mathrm{OH}$ were measured using two high-accuracy static experimental seweups [12-14]. The glass cells were used for vapour pressure measurements lower than ambient pressure at temperatures from
274.15 to $323.15 \mathrm{~K}$. The metal cell was used for the higher temperature range of $323.15-433.15 \mathrm{~K}$ using the static method [12-14]. The glass cell method consists of absolute and differential parts (if the vapour pressure is smaller than the uncertainty of the absolute cell, $30 \mathrm{~Pa}$ ). The vapour pressure of the solution was always higher than the uncertainty of measurements between 274.15 and $323.15 \mathrm{~K}$. The measurements within this temperature range were carried out only using the absolute cell of installation. The internal volume of the glass cell in absolute measurements is approximately $78.56 \mathrm{~cm}^{3}$, and the volume of steel tube cells is $1 \mathrm{~cm}^{3}$. The glass cell static method consists of a bolted-top cell in a water-bath kept at constant temperature $( \pm 0.01 \mathrm{~K})$ using a thermostat.

The vapour pressure was measured using a calibrated high accuracy sensor head [Type 615A connected to the signal conditioner Type 670A, MKS Baratron, USA] attached to the top of the cell of various Keller pressure transmitters: maximum pressure of $300,000 \mathrm{~Pa}$ with an uncertainty of $\Delta P= \pm(400$ to 1,500$)$ $\mathrm{Pa}$, maximum pressure of $1,000,000 \mathrm{~Pa}$ with an uncertainty of $\Delta P= \pm(1,000$ to 5,000$) \mathrm{Pa}$ and maximum pressure of $1,600,000 \mathrm{~Pa}$ with an uncertainty of $\Delta P=$ $\pm(2,000$ to 8,000$) \mathrm{Pa}$. The experimental uncertainty of the pressure in the absolute vapour pressure measurement using the glass cell is $\pm 10-30 \mathrm{~Pa}$.

The internal volume of the measurement cell is approximately $140 \mathrm{~cm}^{3}$. Temperatures were measured using two different platinum resistance thermometers, PT-100. The second platinum resistance thermometer, PT-100, transfers the measured temperature in the computer via an Omega PT-104A Channel RTD Input Data Acquisition Module (Omega Engineering, Inc., USA) for the measuring of temperature, with an accuracy of $\pm 0.001 \mathrm{~K}$. Experiments were carried out starting from a low temperature $(333.15 \mathrm{~K})$ to a high temperature $(433.15 \mathrm{~K})$ at $10 \mathrm{~K}$ intervals.

Before the experiments, the measurement cells were washed with water, methanol and acetone and then all residual fluids were removed. This procedure requires approximately 2 to $3 \mathrm{~h}$ or more to reach the 
Table 2. Experimental mole fraction $x$ of 1-propanol, and vapour pressure $P$ (in Pa) of a solution of $(1-x) \mathrm{C}_{2} \mathrm{H}_{5} \mathrm{OH}+$ $x \mathrm{C}_{3} \mathrm{H}_{7} \mathrm{OH}^{a}$

\begin{tabular}{|c|c|c|c|c|c|c|c|c|}
\hline \multirow{2}{*}{$\begin{array}{c}\text { Temperature } \\
(\mathrm{K})\end{array}$} & \multicolumn{8}{|c|}{ mole fraction of 1-propanol $(x)$} \\
\hline & $0.0000^{\mathrm{b}}$ & 0.0989 & 0.1918 & 0.4034 & 0.5935 & 0.7971 & 0.9038 & $1.0000^{\mathrm{c}}$ \\
\hline 274.15 & 1684 & 1490 & 1374 & 1116 & 897 & 672 & 530 & 515 \\
\hline 278.15 & 2248 & 1980 & 1843 & 1498 & 1219 & 902 & 739 & 697 \\
\hline 283.15 & 3155 & 2810 & 2620 & 2149 & 1761 & 1330 & 1102 & 1008 \\
\hline 293.15 & 5842 & 5390 & 5023 & 4186 & 3442 & 2670 & 2260 & 2034 \\
\hline 303.15 & 10458 & 9762 & 9180 & 7780 & 6521 & 5150 & 4402 & 3854 \\
\hline 313.15 & 18054 & 16872 & 15880 & 13558 & 11502 & 9260 & 8030 & 7048 \\
\hline 323.15 & 29356 & 27918 & 26430 & 22909 & 19560 & 15890 & 13873 & 12273 \\
\hline 333.15 & 46796 & 44590 & 42200 & 36700 & 31777 & 26000 & 22992 & 20472 \\
\hline 343.15 & 71902 & 68812 & 65321 & 57200 & 49784 & 41400 & 36903 & 32867 \\
\hline 353.15 & 108174 & 103196 & 98000 & 86256 & 75504 & 63400 & 56954 & 50997 \\
\hline 363.15 & 157911 & 150535 & 143157 & 126500 & 111128 & 94202 & 85257 & 76746 \\
\hline 373.15 & 224798 & 214272 & 203797 & 180800 & 159521 & 136296 & 123958 & 113402 \\
\hline 383.15 & 313786 & 298327 & 284000 & 252345 & 223518 & 192294 & 176009 & 161109 \\
\hline 393.15 & 429264 & 407124 & 387678 & 345105 & 306612 & 265259 & 244002 & 223982 \\
\hline 403.15 & 576481 & 545340 & 519543 & 462803 & 412430 & 358865 & 331402 & 305477 \\
\hline 413.15 & 759512 & 718454 & 684376 & 610504 & 545107 & 476594 & 441754 & 408702 \\
\hline 423.15 & 982342 & 932045 & 887923 & 792004 & 708954 & 622271 & 578714 & 539077 \\
\hline 433.15 & 1254038 & 1191945 & 1135123 & 1012845 & 907984 & 800473 & 746309 & 702376 \\
\hline 443.15 & 1582042 & 1505202 & 1432927 & 1278187 & 1147706 & 1015139 & 949123 & 893968 \\
\hline
\end{tabular}

${ }^{a}$ Standard uncertainties $u$ are $u(T)=0.01 \mathrm{~K}$ and $u(x)=0.0001$ mole fractions and the combined expanded uncertainties $U_{\mathrm{c}}$ are $U_{\mathrm{c}}(P)=30 \mathrm{~Pa}$ for $P<0.1 \mathrm{MPa}, U_{\mathrm{c}}(P)=1500 \mathrm{~Pa}$ for $P<3 \mathrm{MPa}$, and $U_{\mathrm{c}}(P)=8000 \mathrm{~Pa}$ for $P<16 \mathrm{MPa}$ (level of confidence $=0.95) ;{ }^{b}$ The vapour pressure values of ethanol were taken from Ref. [15]; ${ }^{c}$ The vapour pressure values of 1 propanol were taken from Ref. [16].

desired minimal pressure (20-30 Pa). Equilibration of the cells is a rapid process and a constant pressure in the stationary regime is reached within 15 minutes. Equilibrium pressure readings are performed in triplicate approximately 10 to 20 min intervals.

Specific quantities of ethanol and 1-propanol were evacuated, degassed in two separate flasks and connected using an adapter [12]. Ethanol flowed into a flask containing 1-propanol and the concentration of the solution was determined using the weight of the flask containing the solution on an electronic scale (Sartorius ED224S, Germany) with an uncertainty of $0.0001 \mathrm{~g}$. A quantity of the solution was injected into the equilibrium cells up to approximately $50 \%$ of their volume.

The vapour pressures of the water, methanol, acetone, toluene, 1-butanol, etc. were measured as reference substances for testing both setups [12-14]. The experimental vapour pressure results were assessed to be reliable to within an average uncertainty of $\pm 0.05 \%$ according to test measurements.

\section{Results and Discussion}

The measured experimental vapour pressures for an ethanol/1-propanol mixture within the temperature range of 274.15 to $433.15 \mathrm{~K}$ are listed in Table 2, and are also shown in Fig.1. The vapour pressures of pure alcohols were taken from Refs. [15-16].

The experimental vapour pressure results, $P$ in $\mathrm{Pa}$ of investigated solutions were fit to the Antoine equation:

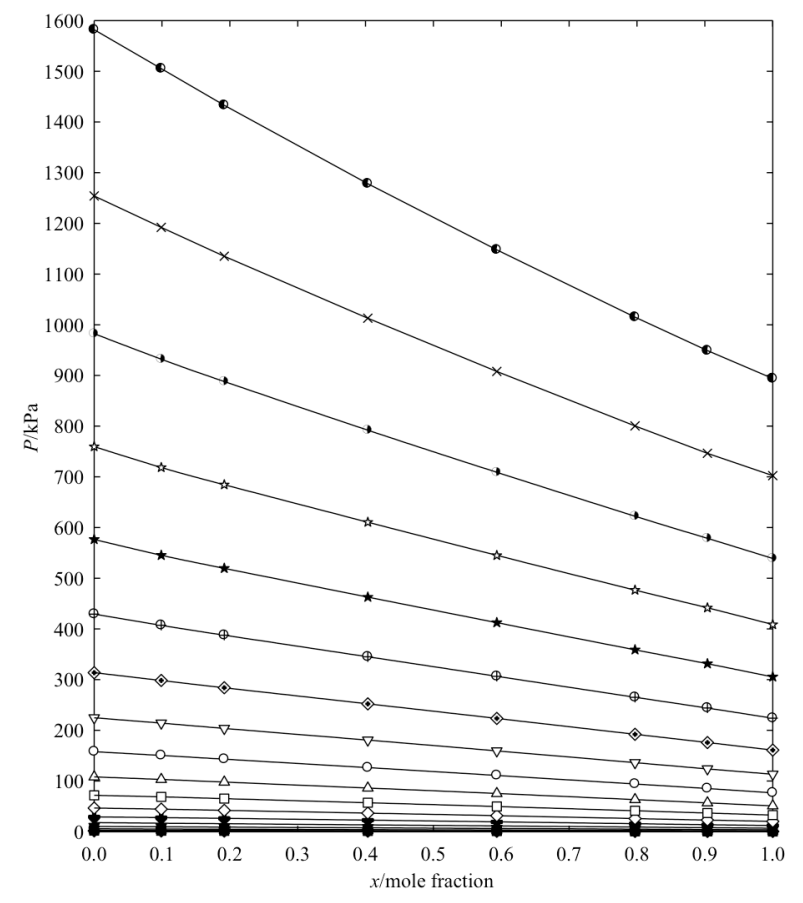

Figure 1. Plot of vapour pressure $P$ (in $\mathrm{kPa}$ ) of a $(1-x) \mathrm{C}_{2} \mathrm{H}_{5} \mathrm{OH}+x \mathrm{C}_{3} \mathrm{H}_{7} \mathrm{OH}$ solution mixture as a function of 1-propanol mole fraction $x$. $\bullet, 274.15 \mathrm{~K}$; $\boldsymbol{\square}, 278.15 \mathrm{~K} ; \boldsymbol{\Delta}, 283.15 \mathrm{~K} ; \bullet, 293.15 \mathrm{~K} ; \boldsymbol{\nabla}, 303.15$ $\mathrm{K} ; \mathbf{x}, 313.15 \mathrm{~K} ; \boldsymbol{+}, 323.15 \mathrm{~K} ; \diamond, 333.15 \mathrm{~K} ; \square$, $343.15 \mathrm{~K} ; \triangle, 353.15 \mathrm{~K} ; \bigcirc, 363.15 \mathrm{~K} ; \nabla, 373.15 \mathrm{~K}$; $\diamond, 383.15 \mathrm{~K} ; \oplus, 393.15 \mathrm{~K} ; \star$, $403.15 \mathrm{~K} ;$ 추, 413.15 $\mathrm{K}, \boldsymbol{\bullet}, 423.15 \mathrm{~K} ; \mathrm{x}, 433.15 \mathrm{~K} ; \bullet, 443.15 \mathrm{~K}$; lines fit to Eqs.(3) and (4).

$$
\ln (P)=\mathrm{A}^{\mathrm{A}}-\mathrm{B}^{\mathrm{A}} /\left(T / K+\mathrm{C}^{\mathrm{A}}\right)
$$


Table 3. Antoine parameters $\mathrm{A}^{\mathrm{A}}, \mathrm{B}^{\mathrm{A}}, \mathrm{C}^{\mathrm{A}}$ and percent deviations $(\triangle P / P$ in $\%)$ as a function of 1-propanol mole fraction.

\begin{tabular}{lcccc}
\hline $\begin{array}{c}\text { mole } \\
\text { fraction }\end{array}$ & $\mathrm{A}^{\mathrm{A}}$ & $\mathrm{B}^{\mathrm{A}}$ & $\mathrm{C}^{\mathrm{A}}$ & $\Delta P / P$ \\
\hline $0.0000^{\mathrm{a}}$ & 23.1773 & 3461.23 & -54.3818 & 0.6234 \\
0.0989 & 22.8524 & 3275.81 & -63.4603 & 0.0742 \\
0.1918 & 22.7353 & 3228.33 & -65.9886 & 0.0689 \\
0.4034 & 22.4745 & 3118.11 & -72.4808 & 0.1652 \\
0.5935 & 22.3425 & 3077.68 & -76.1926 & 0.2204 \\
0.7971 & 22.2692 & 3064.56 & -79.8646 & 0.3263 \\
0.9038 & 22.1582 & 3009.02 & -84.6711 & 0.1983 \\
$1.0000^{\mathrm{b}}$ & 22.7515 & 3373.18 & -70.0769 & 0.8270 \\
\hline
\end{tabular}

${ }^{\mathrm{a}}$ from Ref. [15]; ${ }^{\mathrm{b}}$ from Ref. [16].

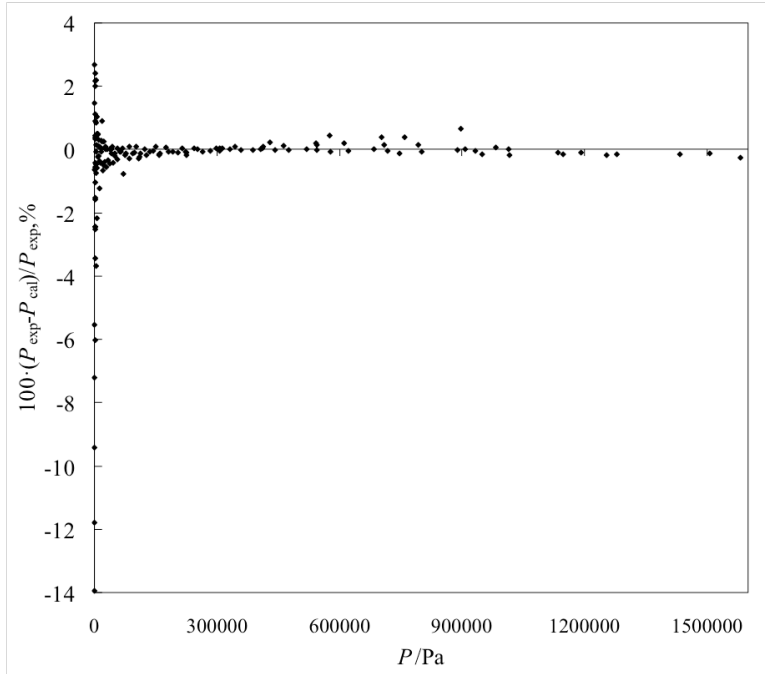

Figure 2. Deviation of experimental $P_{\text {exp }}$ and calculated $P_{\text {cal }}$ vapour pressure values versus pressure $P$ using Eqs.(3) and (4) at various temperatures and mole fractions.

The fitted constants $\mathrm{A}^{\mathrm{A}}, \mathrm{B}^{\mathrm{A}}$, and $\mathrm{C}^{\mathrm{A}}$ for the investigated solutions are summarised in Table 3 with the standard mean deviation defined as follows:

$$
\delta P / P=100 / n \cdot \sum_{i=1}^{n}\left[\left(P_{\text {exp. }}-P_{\text {cal. }}\right) / P_{\text {exp. }}\right]
$$

From Table 3, it can be seen that coefficients $\mathrm{A}^{\mathrm{A}}$, $\mathrm{B}^{\mathrm{A}}$, and $\mathrm{C}^{\mathrm{A}}$ exhibit non-trivial dependence from the mole fraction of 1-propanol. Fitting of these coefficients was a challenging task. Thus, we also used a ClausiusClapeyron-type equation to obtain the vapour pressure results of the investigated solutions from mole fractions of 1-propanol:

$$
\ln p=\mathrm{A}^{\mathrm{CC}}+\frac{\mathrm{B}^{\mathrm{CC}}}{T}+\mathrm{C}^{\mathrm{CC}} \ln T+\mathrm{D}^{\mathrm{CC}} T,
$$

where $P$ is vapour pressure in $\mathrm{Pa} ; T$ is the temperature in $\mathrm{K}$; and $\mathrm{A}^{\mathrm{CC}}, \mathrm{B}^{\mathrm{CC}}, \mathrm{C}^{\mathrm{CC}}$, and $\mathrm{D}^{\mathrm{CC}}$ are the coefficients of the equation, depending on the mole fraction of the solvent as follows:
Table 4. Clausius - Clapeyron equation fitting parameters $a_{\mathrm{i}}, b_{\mathrm{i}}, c_{\mathrm{i}}$, and $d_{\mathrm{i}}$ from Eqs.(3) and (4).

\begin{tabular}{cccc}
\hline$a_{i}$ & $b_{i}$ & $c_{i}$ & $d_{i}$ \\
\hline$a_{0}=103.156$ & $b_{0}=-7994.80$ & $c_{0}=-12.3406$ & $d_{0}=0.0098481$ \\
$a_{1}=251.788$ & $b_{1}=-8366.78$ & $c_{1}=-42.1398$ & $d_{1}=0.0527419$ \\
$a_{2}=222.344$ & $b_{2}=-7727.52$ & $c_{2}=-36.8168$ & $d_{2}=0.0438405$ \\
$a_{3}=-446.740$ & $b_{3}=14403.70$ & $c_{3}=74.8888$ & $d_{3}=-0.0951465$ \\
\hline
\end{tabular}

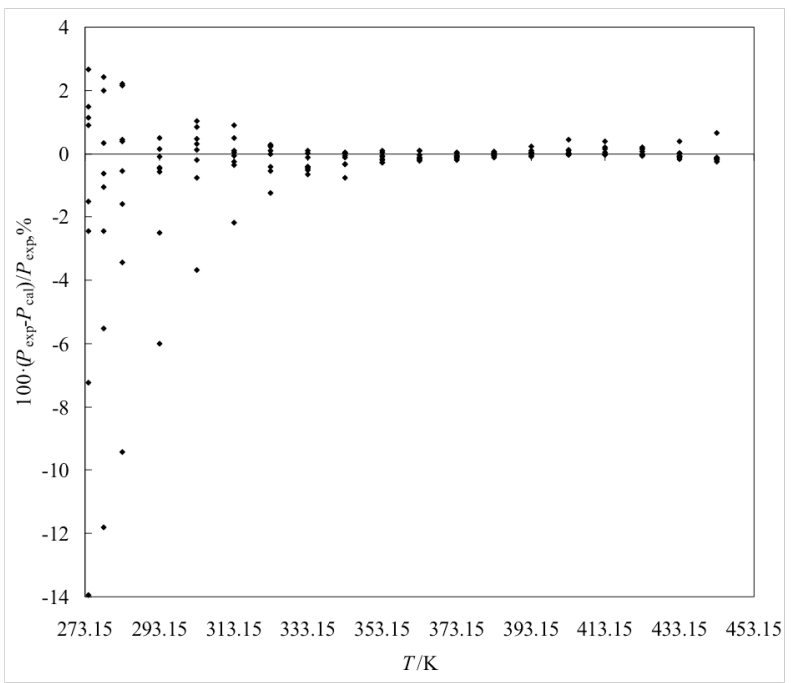

Figure 3. Deviation of experimental $P_{\text {exp }}$ and calculated $P_{\text {cal }}$ vapour pressure values versus temperature $T$ using Eqs.(3) and (4) at various pressures $P$ and mole fractions.

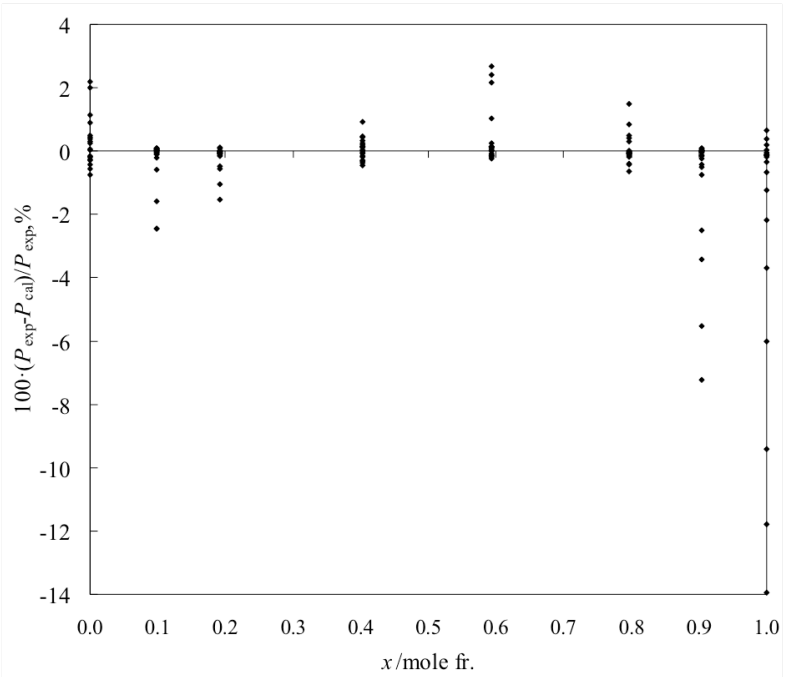

Figure 4. Deviation of experimental $P_{\exp }$ and calculated $P_{\text {cal }}$ vapour pressure values versus mole fraction $x$ using Eqs.(3) and (4) at various pressures $P$ and temperatures $T$.

$\mathrm{A}^{\mathrm{CC}}=\sum_{\mathrm{i}=0}^{3} a_{\mathrm{i}} x^{\mathrm{j}} \mathrm{B}^{\mathrm{CC}}=\sum_{\mathrm{i}=0}^{3} b_{\mathrm{i}} x^{\mathrm{j}} \mathrm{C}^{\mathrm{CC}}=\sum_{\mathrm{i}=0}^{3} c_{\mathrm{i}} x^{\mathrm{j}} \mathrm{D}^{\mathrm{CC}}=\sum_{\mathrm{i}=0}^{3} d_{\mathrm{i}} x^{\mathrm{j}}(4)$

The coefficients $a_{\mathrm{i}}, b_{\mathrm{i}}, \mathrm{c}_{\mathrm{i}}$, and $d_{\mathrm{i}}$ for the investigated ethanol/1-propanol mixtures are tabulated in Table 4. The uncertainty of fitting was approximately $u_{\mathrm{r}}(\Delta P / P)=$ 0.7678 . The plots of deviation of experimental $P_{\exp }$ and calculated $P_{\text {cal }}$ vapour pressure values as a function of 


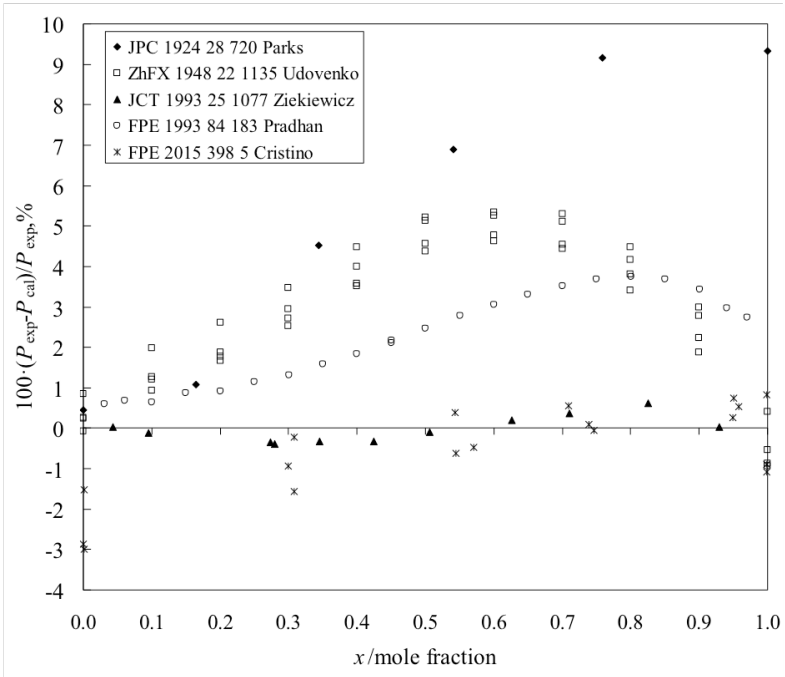

Figure 5. Deviation of experimental $P_{\exp }$ and literature $P_{\text {lit }}$ vapour pressure values for the ethanol/1-propanol mixture versus 1-propanol mole fraction using Eqs.(3) and (4) at various pressures $P$ and temperatures $T$.

pressure, temperature, and mole fraction using Eqs.(3) and (4) are shown in Figs.2-4, respectively.

The enthalpies of vaporisation, $\Delta \mathrm{H}_{\text {vap }}$ in $\mathrm{J} \mathrm{mol}^{-1}$, for the $(1-x) \mathrm{C}_{2} \mathrm{H}_{5} \mathrm{OH}+x \mathrm{C}_{3} \mathrm{H}_{7} \mathrm{OH}$ mixture at the four middle temperatures $(293.15,333.15,373.15$, and 423.15 within temperature ranges of $274.15-313.15 \mathrm{~K}$, 313.15-353.15 K, 353.15-393.15 K, and 373.15-443.15 $\mathrm{K}$, respectively) were defined using Eq.(5) from Ref. [12]:

$$
\frac{d \ln P}{d\left(\frac{1}{T}\right)}=-\frac{\Delta H_{\mathrm{v}}}{\mathrm{R}}
$$

If we plot $\ln (P)$ as a function of $1 / \mathrm{T}$, we can define $\Delta H_{\mathrm{v}}$ from the gradient of the line:

$$
\Delta H_{\mathrm{v}}=-\mathrm{R} \cdot \frac{d \ln P}{d\left(\frac{1}{T}\right)} .
$$

After the integration of Eq.(6) we can find

$$
\begin{gathered}
\ln p=\left(-\frac{\Delta H_{\mathrm{v}}}{\mathrm{R}}\right)\left(\frac{1}{T}\right)+\text { intercept } \\
\Delta H_{\mathrm{v}}=\mathrm{R} T(\text { intercept }-\ln P)
\end{gathered}
$$

The calculated enthalpy of vaporisations $\Delta H_{\mathrm{v}}$ in $\mathrm{J}$ mol $^{-1}$ for the $(1-x) \mathrm{C}_{2} \mathrm{H}_{5} \mathrm{OH}+x \mathrm{C}_{3} \mathrm{H}_{7} \mathrm{OH}$ mixture within the temperature range of $274.15-443.15 \mathrm{~K}$ are listed in Table 5 and compared to the available literature results [7-11] shown in Fig.5.

When the measured values by Parks [7] at $T=$ $298.15 \mathrm{~K}$ are compared to our values, we obtain $\Delta P=$ $\pm 242 \mathrm{~Pa}$ or $\Delta P / P= \pm 5.24 \%$ deviations. The maximum deviation is $\Delta P=394 \mathrm{~Pa}$ at $x=0.759$ mole fractions of
Table 5. Enthalpy of vaporisation, $\Delta H_{\mathrm{v}}$ in $\mathrm{kJ} \mathrm{mol}^{-1}$ for a $(1-x) \mathrm{C}_{2} \mathrm{H}_{5} \mathrm{OH}+x \mathrm{C}_{3} \mathrm{H}_{7} \mathrm{OH}$ mixture at various temperatures.

\begin{tabular}{ccccc}
\hline$x$ & $293.15 \mathrm{~K}$ & $333.15 \mathrm{~K}$ & $373.15 \mathrm{~K}$ & $423.15 \mathrm{~K}$ \\
\hline 0.0000 & 43.245 & 41.210 & 39.579 & 37.457 \\
0.1574 & 43.905 & 41.300 & 39.542 & 37.576 \\
0.2876 & 44.499 & 41.416 & 39.425 & 37.553 \\
0.5351 & 45.768 & 41.989 & 39.707 & 37.718 \\
0.7130 & 46.768 & 42.811 & 40.157 & 38.002 \\
0.8699 & 47.809 & 43.815 & 40.965 & 38.613 \\
0.9411 & 47.887 & 44.441 & 41.546 & 39.125 \\
1.0000 & 47.908 & 45.052 & 42.330 & 39.963 \\
\hline
\end{tabular}

1-propanol. The Parks' values [7] are higher than our results and the vapour pressures of ethanol exhibit small deviations compared to ours and all other literature values presented in Ref. [15]. The vapour pressure of 1propanol published in Ref. [7] exhibits a large deviation from ours and all other literature values presented in Ref. [16]. We hypothesise that the vapour pressure values of 1-propanol with high deviation from the literature were used during the analysis of concentration dependence in Ref. [7].

The 44 data points of Udovenko and Frid [8] measured within the range of $323.15-353.15 \mathrm{~K}$ are mostly higher than our values. The average deviations of both sources are $\Delta P= \pm 242 \mathrm{~Pa}$ and $\Delta P / P= \pm 5.24 \%$ with maximum deviations of $\Delta P=2952 \mathrm{~Pa}$ at $T=$ $343.15 \mathrm{~K}$ and $x=0.5$ mole fractions of 1-propanol.

The 11 data points of Zielkiewicz [9] at $T=313.15$ $\mathrm{K}$ exhibit small deviations from our results with $\Delta P=$ $\pm 33 \mathrm{~Pa}$ and $\Delta P / P= \pm 0.2631 \%$ mean deviation. The maximum obtained deviation in $\Delta P=-59 \mathrm{~Pa}$ at $x=$ 0.2793 mole fractions of 1-propanol.

The next 22 data points of Pradhan et al. [10] are mostly higher than our values. The average mean deviation of this comparison is $\Delta P= \pm 143 \mathrm{~Pa}$ and $\Delta P / P$ $= \pm 2.2378 \%$. The maximum obtained deviation in $\Delta P=$ $209 \mathrm{~Pa}$ and $\Delta P / P= \pm 3.5182 \%$ at $T=303.15 \mathrm{~K}$ and $x=$ 0.7002 mole fractions of 1-propanol.

The last 18 experimental values from the recent work of Cristino et al. [11] measured at high vapour pressure intervals of $304.2-967.4 \mathrm{kPa}$ also exhibit small differences from our values as the mean deviation between two experimental sources is $\Delta P= \pm 5698 \mathrm{~Pa}$ and $\Delta P / P= \pm 0.9227 \%$. The maximum deviation of this comparison is $\Delta P=-21134 \mathrm{~Pa}$ at $T=413.2 \mathrm{~K}$ and $x=$ 0.0002 mole fractions of 1-propanol.

\section{Conclusion}

Vapour pressure measurements for the binary mixture of ethanol and 1-propanol over a wide range of temperatures from $274.15 \mathrm{~K}$ to $468.15 \mathrm{~K}$ were studied. The Antoine and Clausius-Clapeyron equations were used to fit the experimental results. The enthalpies of vaporisation at four various temperatures were calculated. The available literature values were compared with measured values and small deviations were observed. 


\section{Acknowledgement}

The research was supported by University of Rostock and Azerbaijan Technical University

\section{REFERENCES}

[1] Cano-Gómez, J.J.; Iglesias-Silva, C.A.; RamosEstrada, M.; Hall, K.R.: Densities and viscosities for binary liquid mixtures of ethanol + 1-propanol, 1-butanol, and 1-pentanol from 293.15 to $328.15 \mathrm{~K}$ at 0.1 MPa, J. Chem. Engng. Data, 2012 57, 2560-2567 DOI 10.1021/je300632p

[2] Kumagai, A.; Yokoyama, C.: Liquid viscosity of binary mixtures of methanol with ethanol and 1propanol from $273.15 \mathrm{~K}$ to 333.15 , Int. $J$. Thermophys., 1998 19, 3-13

[3] Aliyev, F.Sh.; Safarov, J.T.; Talibov, M.A.; Shahverdiyev, A.N.: Temperature and pressure dependence of density of the methanol and 1propanol solutions, J. Fundam. Sci. Azerbaijan Technical Uni., 2008 7(3), 55-61

[4] Abdulagatov, I.M.; Aliyev, F.Sh.; Safarov, J.T.; Talibov, M.A.; Shahverdiyev, A.N.; Hassel, E.: High-pressure densities and derived volumetric properties (excess and partial molar volumes, vapour-pressures) of binary methanol + ethanol mixtures, Thermochimica Acta, 2008 476(1-2), 5162 DOI 10.1016/j.tca.2008.07.011

[5] Aliyev, F.Sh.; Safarov, J.T.; Talibov, M.A.; Shahverdiyev, A.N.: $(p, \varrho, T)$ properties of ethanol and 1-propanol solutions, J. Fundam. Sci. Azerbaijan Technical Uni., 2008 7(1), 35-39

[6] Safarov, J.T.; Aliyev, F.Sh.; Talibov, M.A.; Shahverdiyev, A.N.: Experimental densities of methanol +1 -propanol at temperatures from 298.15 to $423.15 \mathrm{~K}$ and at pressures up to $40 \mathrm{MPa}$, Proc. $18^{\text {th }}$ Eu. Conf. Thermophysical Prop. (Pau, France) 2008 p. 45

[7] Parks, G.S.; Schwenk, J.R.: Some physicalchemical prop. of mixtures of ethyl and n-propyl alcohols, J. Phys. Chem., 1924 28(7), 720-729 DOI 10.1021/j150241a004
[8] Udovenko, V.V.; Frid, Ts.B.: Evaporation heat in binary mixtures: II. Zh. Fiz. Khim., 1948 22(9), 1135-1145

[9] Zielkiewicz, J.: Vapour + liquid equilibria in heptane + ethanol + propan-1-ol at the temperature 313.15 K, J. Chem. Thermodyn., 1993 25(9), 1077-1082 DOI 10.1006/jcht.1993.1105

[10] Pradhan, A.G.; Bhethanabotla, V.R.; Campbell, S.W.: Vapour-liquid equilibrium data for ethanoln-heptane-1-propanol and ethanol- n-heptane-2propanol and their interpretation by a simple association model, Fluid Phase Equil., 1993 84, 183-206 DOI 10.1016/0378-3812(93)85123-4

[11] Cristino, A.F.; Morgado, P.; Galindo, A.; Filipe, E.J.M.; Palavra, A.M.F.; Nieto de Castro, C.A.: High-temperature vapour-liquid equilibria for ethanol-1-propanol mixtures and modeling with SAFT-VR, Fluid Phase Equil., 2015 398, 5-9 DOI 10.1016/j.fluid.2015.04.009

[12] Safarov, J.T.; Kul, I.; Talibov, M.A.; Shahverdiyev, A.N.; Hassel, E.: Vapour pressures and activity coefficients of methanol in binary mixtures with 1-hexyl-3-methylimidazolium bis(trifluoromethylsulfonyl)imide, J. Chem. Engng . Data, 2015 60(6), 1648-1663 DOI 10.1021/je501033z

[13] Talibov, M.A.; Safarov, J.T.; Shahverdiyev, A.N.; Hassel, E.: Vapour pressure of geothermal and mineral waters of Yardimli district of Azerbaijan, Herald Kazan State Technol. Uni., 2014 17(2), 114-118

[14] Safarov, J.T.; Ahmadov, B.; Mirzayev, S.; Shahverdiyev, A.N.; Hassel, E.: Vapour pressures of 1-butanol over wide range of temperatures, chemistry, Bulgarian J. Sci. Ed., 2015 24(2), 226246

[15] Talibov, M.A.; Safarov, J.T.; Shahverdiyev, A.N.; Hassel, E.: Vapour pressure of ethanol in a wide range of temperature, Azerbaijan Nat. Acad. Sci., Ser. Phys. Math. Techn. Sci., 2015 2, 61-71

[16] Talibov, M.A.; Safarov, J.T.: Vapour pressure of 1propanol in a wide range of temperature, Azerbaijan Nat. Acad. Sci., Ser. Phys. Math. Techn. Sci., 2016 2, in press 